\title{
1 THE JAPANESE ECONOMY: WHERE IS IT LEADING IN THE ASIA PACIFIC?
}

ANATOMY OF AN ABNORMAL ECONOMY AND POLICY FAILURE

\section{Paul Sheard}

The fifteen years until 2005-the post-bubble period —was a challenging one for the Japanese economy. It is almost as if history had played a trick on Japan. At the end of the 1980s, Japan had been riding on the crest of a bubble economy. The stock market and land prices had soared, real GDP had averaged close to 5 per cent year-on-year for the previous five years (and nominal growth more than 6 per cent), and the coming 'Pacific century' appeared to be Japan's for the taking. By 2005, the stock market was less than 40 per cent of its end 1989 peak and official land prices were still falling, trailing five-year average real GDP growth was less than 2 per cent (and nominal growth slightly negative), and Japan had ceded the economic limelight - if not future economic leadership in Asia - to China.

How did this happen? I believe that Japan's prolonged deflation in the post-bubble period was largely a 'policy story' and that the answer to that question lies in understanding the policy challenges and how, in my view, they were largely mishandled. Understanding this is also the key to formulating an informed view of what may lie ahead for the Japanese economy. Will the economy remain in a prolonged quasi-deflationary state or will it fully normalise and resume vigorous non-deflationary growth? 
Lurking below the policy story there may well be a more fundamental political story, but I will leave that to others to tell.

\section{Japan's abnormal economy}

As of 2005, the Japanese economy was in an abnormal state of affairs. There are three related ways in which Japan was not a 'normal economy', and these abnormalities all can be traced to the bubble economy and how its unwinding was mishandled.

The first abnormality is that deflation reigned in Japan. The second is that the government continued to prop up the banking system. The third is that the central bank operated monetary policy at the zero interest rate, bound under a policy of 'quantitative easing'. In a normal economy, there is moderate inflation, banks stand on their own feet, and the central bank targets interest rates. Japan enjoyed none of these features.

The three abnormalities were closely inter-related. To boil down the story of how they came about, the bursting of the asset bubble of the 1980s wreaked havoc on financial and corporate balance sheets and rendered inoperable the bank credit transmission mechanism. Monetary policy was slow to react and poorly coordinated with fiscal policy (and other policies) and the economy slipped into deflation, undermining the potency of monetary policy. To stave off a run on the banking system, the government guaranteed all bank deposits and this slowed down the necessary balance sheet adjustment process, which in turn further stymied the effectiveness of monetary policy. The Bank of Japan kept easing monetary policy, but eventually cut interest rates as far as they could go- that is, to zero-after which it adopted a policy of quantitative easing, supplying progressively more reserves to the banking system than was needed for a zero interest rate. This is how Japan ended up with deflation, a protected banking system, and quantitative easing.

There is an irony here, because the 'abnormal' conditions had been in existence for so long that they had become 'normal' features of the contemporary Japanese economic landscape. Take deflation. The GDP had been falling in year-on-year terms since the second half of 1994 (adjusting for the impact of the 2 per cent increase in the consumption tax in fiscal 1997). By the second quarter of 2004, it was -1.6 per cent 
year-on-year. The Bank of Japan focused on the core CPI as the important measure of inflation in conducting its monetary policy: the year-on-year rate of change in the core CPI had been below 1 per cent since May 1994 and had been below zero for most of the period.

The government had been using extraordinary guarantees to prop up the banking system since June 1995. Under the legal framework at the time, only small-lot deposits were automatically guaranteed by deposit insurance, but as an emergency measure the government announced that all bank deposits would be guaranteed until the end of March 2001. In the event, the government decided in December 1999 to extend the blanket guarantee on large-lot demand deposits until the end of March 2003 and then decided again in October 2002 to extend the guarantee until the end of March 2005. Even then, zero-interest-bearing large-lot demand deposits continued to be fully guaranteed permanently, and a framework existed that automatically guaranteed all deposits whenever the government judged that there was a threat to the maintenance of financial stability. In other words, the abnormal situation of the government guaranteeing the claims of large creditors on the banking system, rather than the banks using their own capital to do so, appeared to be a permanent feature of the regulatory landscape in Japan.

As for abnormal monetary policy, this was also virtually a decade-long phenomenon. The Bank of Japan operated quantitative easing regime for five years from March 2001 to March 2006. However, except for a short period (August 2000-March 2001) when a clear policy error was committed, the Bank of Japan operated monetary policy at the zero interest rate bound for the seven years (since February 1999). And for the three and a half years before then, the Bank of Japan targeted the extraordinary low rate of 50 basis points or less.

The three abnormalities are also closely related in terms of the logic of why the conditions persisted in this way. Again I will boil down the story. Because deflation continued, monetary policy was tighter than the Bank of Japan would like it to be, given that real policy rates were positive and could not be pushed into negative territory (unlike what the Fed has been able to do in the United States twice in the past decade or so). Because banks have been given years to work through their balance sheet problems 
slowly, the credit transmission mechanism remains impaired and the banking system did not create credit, undermining the effectiveness of monetary policy. And because deflation continued, the asset values in the banking system continued to erode. Meanwhile, to strengthen its policy stance, the Bank of Japan committed to maintain quantitative easing for as long as deflation (as measured by the core CPI) continued. Deflation, impaired banks needing government support, and zero interest rates/ quantitative easing all formed a mutually reinforcing set of equilibrium conditions.

\section{Anatomy of the policy response to the bursting of the bubble}

Let us delve a little more into how the Japanese economy got to this state by focusing on how policymakers responded to the unwinding of the bubble of the 1980s. That can be summarised in one word: forbearance.

Japan's asset price bubble of the 1980s, weighted by the size of the Japanese economy, may have been the biggest bubble in recorded financial history (Figure 1.1). The broadest index of land prices in Japan more than doubled from the start of the 1980 s to when it peaked, and

Figure 1.1 Japan's real estate price bubble, 1956-2006 (index, Q1

$1956=1$ )

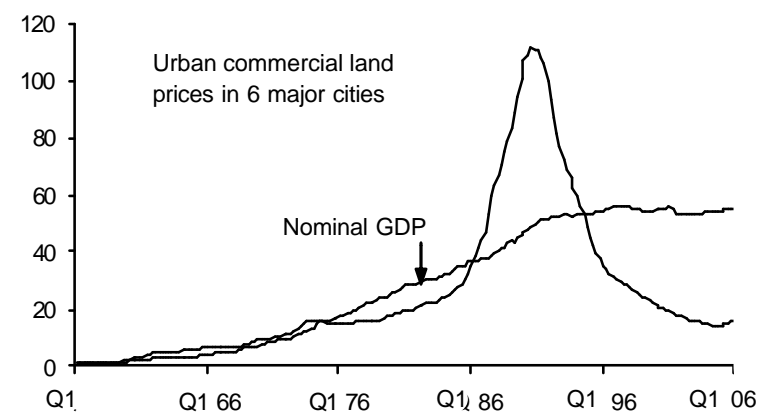

Sources: Bloomberg; Japan Real Estate Institute; Cabinet Office. 
Table $1.1 \quad$ Japanese land prices: measuring the size of the bubble

\begin{tabular}{|c|c|c|c|c|c|c|}
\hline & $\begin{array}{c}\text { Q1 } 04 \\
\text { (\% change } \\
\text { h-o-h) }\end{array}$ & $\begin{array}{c}\text { Q1 } 04 \\
\text { (\% change } \\
\text { y-o-y) }\end{array}$ & $\begin{array}{c}\text { Increase } \\
\text { from } 1980 \\
\text { to peak }(x)\end{array}$ & $\begin{array}{l}\text { Q1 } 04 \text { as } \\
\% \text { of peak }\end{array}$ & \multicolumn{2}{|c|}{$\begin{array}{c}\text { Q1 } 04 \\
\text { level } \\
\text { lowest since }\end{array}$} \\
\hline \multicolumn{7}{|l|}{ Nationwide } \\
\hline All land & -4.1 & -8.4 & 2.09 & 50.3 & Q3 & 80 \\
\hline Commercial & -5.0 & -10.2 & 2.28 & 33.7 & Q1 & 73 \\
\hline Residential & -3.2 & -6.4 & 2.07 & 64.8 & Q1 & 84 \\
\hline Industrial & -4.4 & -8.7 & 1.88 & 62.7 & Q1 & 82 \\
\hline \multicolumn{7}{|l|}{ Six urban areas } \\
\hline All land & -3.4 & -7.4 & 4.29 & 24.5 & Q3 & 80 \\
\hline Commercial & -2.3 & -6.0 & 6.26 & 12.9 & Q1 & 73 \\
\hline Residential & -2.6 & -5.9 & 3.72 & 34.5 & Q1 & 84 \\
\hline Industrial & -5.5 & -10.9 & 3.32 & 32.3 & Q1 & 81 \\
\hline Tokyo (23 wards) & -0.8 & -2.7 & n.a. & 17.5 & & n.a. \\
\hline Osaka (13 cities) & -5.0 & -10.2 & n.a. & 23.5 & & n.a. \\
\hline Nagoya (11 cities) & -3.4 & -6.7 & n.a. & 53.3 & & n.a. \\
\hline Non-big-6 urban & -4.2 & -8.5 & n.a. & 51.2 & & n.a. \\
\hline
\end{tabular}

Sources: Japan Real Estate Institute; Bloomberg.

subsequently has almost halved (Table 1.1). The real estate price bubble was most acute for commercial property in the major urban areas: the index of commercial land prices in the six major urban areas increased more than six-fold in the 1980s and has fallen by 87 per cent since the peak. Notwithstanding some signs of bottoming in parts of Tokyo, all major land price indexes in Japan are still falling in year-on-year terms. Even after fourteen years, real estate prices in Japan continued to deflate.

The bursting of the stock market and real estate price bubble had the predictable effect of throwing the economy into recession in the early 1990s. Industrial production-to quote one statistic - fell by 14.4 per cent from its peak in mid-1991 to its trough at the beginning of 1994 . Thus began a period of prolonged low growth, deflation, and financial system problems, which continued for more than a decade (Figures 1.2 and 1.3). In the ten years to 2005, real GDP growth in Japan averaged 1.2 per cent year-on-year while nominal GDP growth has averaged just 0.2 per cent (the GDP deflator fell by 1.0 per cent on average). In the 
Figure 1.2 Japan's real GDP growth, 1982-2006 (per cent yearon-year, four-quarter moving average)

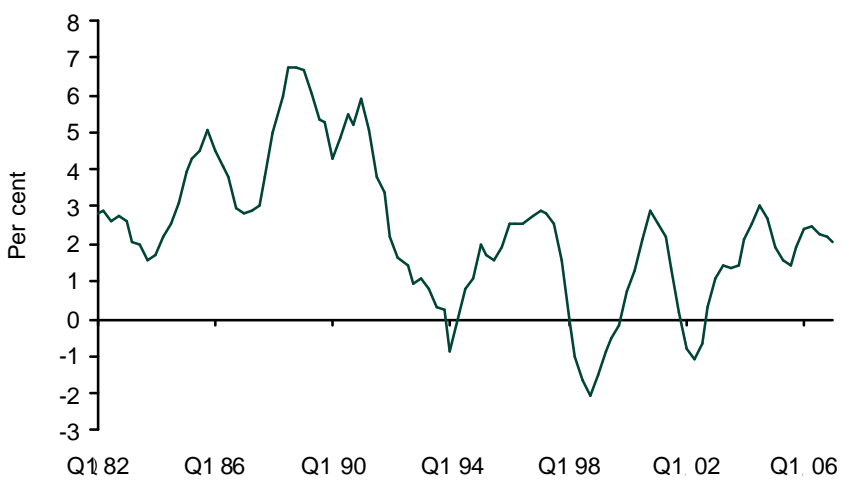

Sources: Cabinet Office; Consensus Economics.

Figure 1.3 Japan's nominal GDP growth and GDP deflator, 1982-2006 (per cent year-on-year, four-quarter moving average)

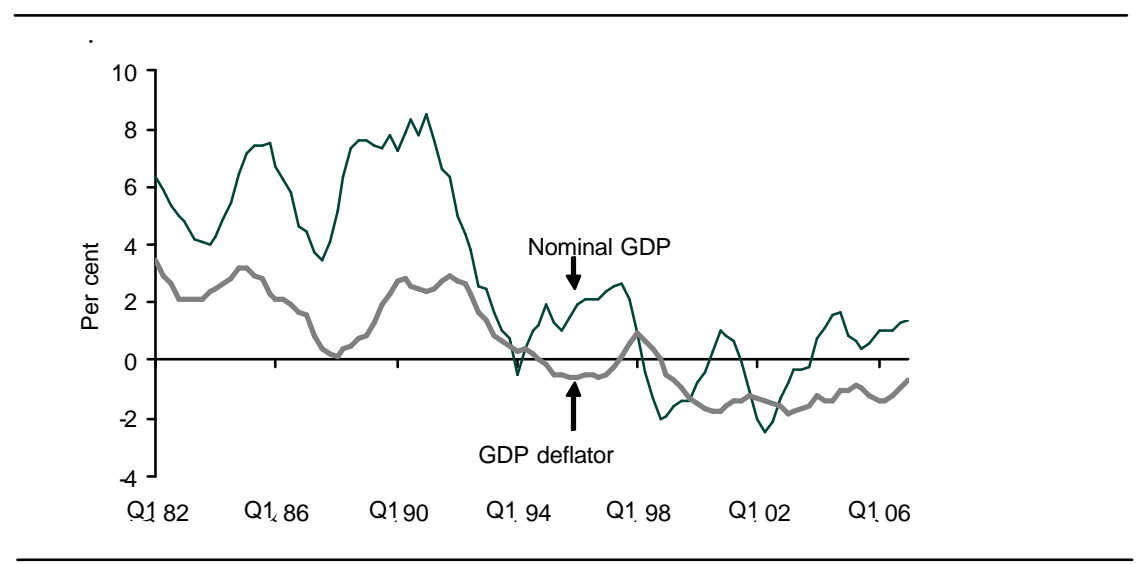

Source: Cabinet Office. 
prior five years, economic performance had been particularly dismal: real GDP in Japan grew on average by 1.3 per cent year-on-year, but nominal GDP actually fell by 0.1 per cent (the GDP deflator fell by 1.3 per cent on average). This is a far cry from the second half of the 1980s (let alone the earlier 'high growth period') when real GDP growth averaged 4.8 per cent year-on-year while nominal GDP growth averaged 6.3 per cent (the GDP deflator rose by 1.7 per cent on average).

A more serious consequence of the unwinding of the bubble than an initial nasty recession was the impact that the loss of asset values had on the banking system: thus began the non-performing loan (NPL) problem (Figure 1.4) and the ongoing process of debt de-leveraging in the corporate sector (Figure 1.5). Bank lending growth decelerated sharply and bank lending began to fall in 1996, and the stock of outstanding bank lending was down 150 trillion yen (28 per cent, or equivalent to 30 per cent of GDP) since that time. The Bank of Japan started cutting the official discount rate in 1991, after it had raised it progressively to 6 per cent from June 1989 to August 1990 in order to 'prick' the bubble, taking it to 0.5 per cent by September 1995 . However, with the banking system sitting on a dramatically escalating, but as yet undisclosed, asset impairment problem, despite the Bank of Japan's monetary policy actions, the economy slipped into deflation: the domestic corporate goods price (then the domestic wholesale price index) started falling in year-on-year terms at the end of 1991, the GDP deflator in the third quarter of 1994 , and, on a sustained basis, the core CPI in the second half of 1998 (Figure 1.6).

By the end of the 1990s, deflation was entrenched (and real estate prices were continuing to fall), the banking system was propped up by the government but was dysfunctional in creating credit, monetary policy was stretched to its conventional limits, and the fiscal finances were deteriorating steadily; to boot, periodic bouts of a strong yen threatened to make matters worse, the export sector being the strongest pillar in the economy.

How did Japanese policymakers respond to the bursting of the bubble and the collateral damage that this caused to the financial system and to the economy? With a mixture of reactive crisis management and policies 
Figure 1.4 Official non-performing loans of all banks, 1992-2005 (yen trillion)

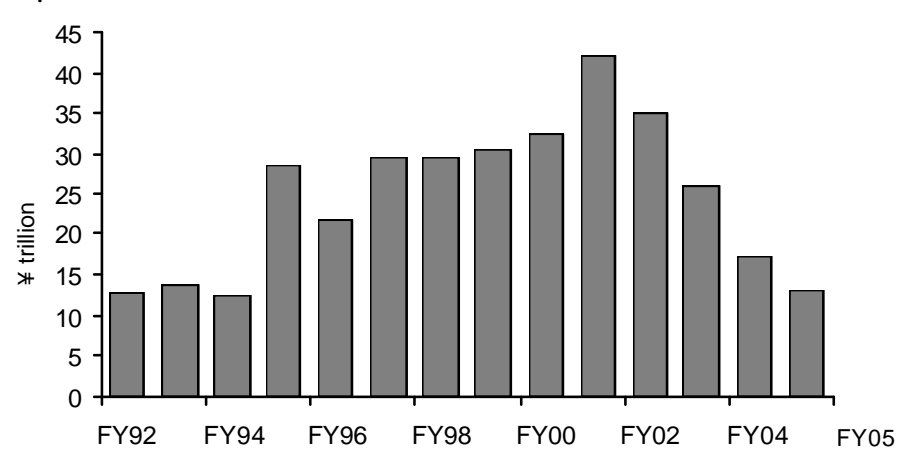

Source: Financial Services Agency.

Figure 1.5 Corporate debt to nominal GDP, 1970-2000 (per cent)

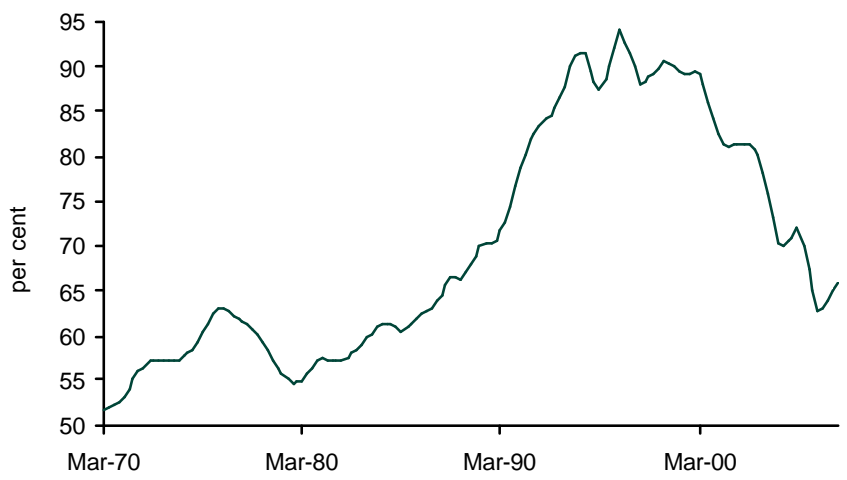

Sources: Ministry of Finance; Cabinet Office. 
Figure 1.6 Measures of deflation, 1990-2006 (index; levels)

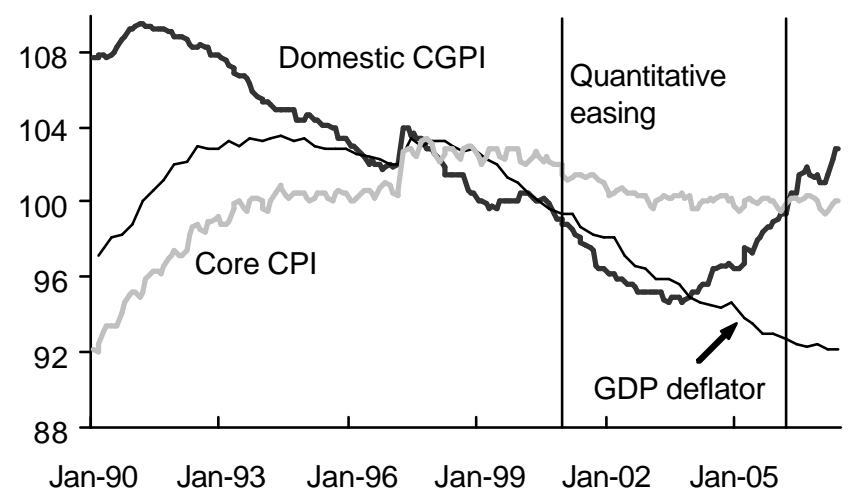

Sources: Bank of Japan; Cabinet Office.

aimed at helping the economy to grow slowly out of the problems, taking as much time as necessary. The two key planks of post-bubble policy were blanket government guarantees of bank deposits and easy monetary policy, which was later implemented as 'quantitative easing'. Having put in the necessary policy planks to buy time, the government did implement some proactive policies aimed at promoting growth: as discussed further below, monetary policy was used as the growth-stimulating policy of choice; fiscal policy was used intermittently to try to spur growth (but in a flawed way); and there was ongoing deregulation both in the private sector and the public sector, which supported growth over time.

The single most important policy, in my view, for understanding the course of Japan's economy in the post-bubble period, is the government guarantee of bank deposits, as innocuous a policy as this may sound to many observers. Real estate prices began falling in 1990, as policymakers successfully 'pricked' the bubble, and small banks and credit unions began to fail shortly after. However, it was not until the fallout from the failure of two Tokyo credit unions at the end of 1994 (and the dramatic rise in the 
yen and collapsing stock market in early 1995) focused the minds of policymakers on the fallout of the bursting of the bubble that the issue came to be addressed as a systemic one. On 8 June 1995, the Ministry of Finance made a momentous announcement: all bank deposits, not just those covered by the existing deposit insurance system, would be guaranteed by the government, and a five-year plan (later set to end at the end of March 2001) would be implemented to 'cope with the nonperforming loan problem' (Ministry of Finance 1995). Forbearance policy had moved from implicit to official policy.

The decision by the government to stand behind all bank deposits was by no means inevitable. The deposit insurance system guaranteed 'smalllot deposits', that is, deposits up to 10 million yen per depositor per bank, which comprised about half of all bank deposits in total (Figure 1.7). The blanket guarantee extended this guarantee to large-lot depositors, who in legal terms at that point were unsecured creditors on the banking system, or creditors who relied on the strength of bank capital to secure their claims. No bank depositor had lost money in the postwar period,

Figure 1.7 Evolution of the government guarantee on bank deposits, 1992-2007 (per cent of total deposits)

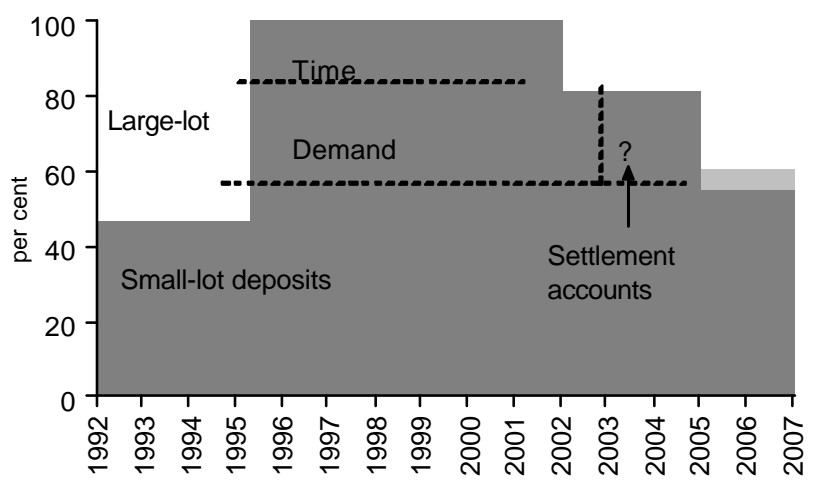

Source: Compiled on basis of Bank of Japan data. 
notably in the first half of the 1990s during which period seven institutions had already failed: the government always engineered a rescue merger, and since 1991 these deals were sweetened by the Deposit Insurance Corporation providing financial assistance to the rescuing bank.

The situation was so bad by 1995, however, that, had the government not announced that all bank deposits, not just small-lot deposits, would be fully guaranteed, a run on the banking system and a financial crisis would have surely ensued sooner or later. Policymakers never seem to have contemplated the option of not extending a blanket guarantee to all bank deposits. Some sort of banking system 'crisis' would have ensued in that case, as non-secured investors in the banking system realised that the asset backing for their deposits had gone up in smoke with the collapse in asset values and that the government was not going to step in kindly to make them whole. Policymakers would have needed to have been on their toes to prevent a full-fledged melt-down of the financial system (Table 1.2).

But a 'financial crisis' can be one way of bringing balance sheets into line with economic realities and of confronting and dealing with underlying financial system problems. A decision not to guarantee all deposits would have been a decision to allow the losses from the bursting of the bubble to have fallen where they lay - on the direct and indirect owners of the assets. It would have been a decision to confront, rather than delay, the recognition and resolution of the underlying asset market and balance sheet problems. It would have been the financial system equivalent of letting water flow downhill.

The June 1995 decision was crisis management, but little else. The decision obviated the need for depositors to withdraw deposits from the banking system, but the assets that had been lost were not going to come back. No government wants a financial crisis on its hands, so one can have some sympathy with the government's decision to guarantee all bank deposits. But all this did was to buy time to deal with the underlying problems, and it did so by transferring any contingent losses of bank depositors to the government, that is, to taxpayers. The government's decision meant that taxpayers were bailing out bank depositors in order to secure financial stability in the face of a massive impairment of assets in the banking system. This was a legitimate (and, most observers argued, 


\section{Table 1.2 Current cyclical upswing compared with previous two post-bubble recoveries, 1993, 1999 and 2002}

(a) Contribution of components to real GDP growth (ppp) purchasing power parity

\begin{tabular}{lccccc} 
& \multicolumn{3}{c}{ Through of recovery cycle } & & Last three \\
& Q3 93 & Q1 99* & Q1 02 & & quarters \\
\cline { 2 - 4 } \cline { 5 - 6 } GDP & 4.6 & 5.3 & 8.2 & & 3.9 \\
Final private domestic demand & 3.6 & 4.0 & 5.4 & \\
$\quad$ Consumption & 3.3 & 1.6 & 2.5 & 1.5 \\
$\quad$ Business investment & 0.2 & 2.1 & 3.0 & 1.5 \\
$\quad$ Residential investment & 0.1 & 0.2 & 0.0 & 0.0 \\
Inventory investment & 0.3 & 0.9 & 1.6 & 0.3 \\
Public demand & 1.9 & 0.3 & -1.0 & -0.3 \\
Net exports & -1.2 & 0.2 & 2.2 & 1.0 \\
Reference: GDP deflator & -0.7 & -3.6 & -6.0 & -2.4
\end{tabular}

(b) Contribution of components to nominal GDP growth (ppp) purchasing power parity

GDP Through of recovery cycle Last three

Final private domestic demand

\begin{tabular}{r} 
Q3 93 \\
\hline 4.0 \\
2.9 \\
3.2 \\
-0.3 \\
0.1 \\
0.3 \\
1.9 \\
-1.2 \\
3.2
\end{tabular}
Q1 99* Q1 02 Consumption 2.9

1.5

$\frac{\text { quarters }}{1.4^{\prime}}$

Business investment

3.2

1.7

1.8

1.6

Residential investment

0.2

0.7

0.9

Inventory investment

0.3

1.2

1.1

0.8

0.2

0.0

0.0

Public demand

1.9

0.8

1.2

0.0

Net exports

0.0

$-2.0$

$-.05$

Reference: Worker compensation

* This recovery lasted for just eight quarters

Source: Cabinet Office.

compelling) policy decision, but the ramifications - that the lost assets were unlikely to come back and that somebody, presumably the government, would have to foot the bill-should have been better understood and acted upon. The government should have followed up its momentous decision to guarantee deposits with a commensurate injection of public funds into the banking system to make bank balance sheets whole. This could have been done through a carve-out of NPLs at or close 
to face value to a 'resolution and trust corporation'-style entity, or by injecting a large amount of common equity, that is, equity not required to be re-paid: the government did neither (although much later pale versions of these policies were implemented).

A major flaw in banking system policy in Japan in this period is that policymakers have never accepted, or even acted as if they realised, that guaranteeing bank deposits to head off a financial crisis and injecting fiscal funds are two sides of the same policy coin. Moreover, in a classic circular argument, because the blanket guarantees succeeded in preventing financial instability (particularly a run on bank deposits), policymakers were consistently able to deny the need to inject public funds, on the grounds that were was no crisis.

The government did not want a financial crisis - that is, a marketbased resolution to the fact that market values of assets were way below their book values_-but it did not want to foot the bill for a bailout either, although this would have allowed the whole episode of the bubble and its aftermath to have been assigned to the history books relatively quickly. That just left forbearance as their underlying policy: playing for time and banking on growth to eventually heal balance sheet wounds. Notwithstanding some stop-start attempts to use fiscal policy to stimulate growth, policymakers clearly looked to monetary policy to be the mainstay of macro stimulus. The Bank of Japan dropped policy interest rates from 1.75 per cent at the start of the year to 50 basis points by September of 1995, a level of rates seen at the time as 'extraordinary'. However, by the time that the 'financial stabilisation five-year plan' had been put in place, the economy had already slipped into deflation, meaning that the Bank of Japan had lost the opportunity to give the economy a shot in the arm by experiencing negative real rates, and land prices were continuing to plummet. In fact, exemplifying another inconsistent cross-current in policy, the official policy goal of bringing down land prices-adopted at the start of the decade - continued to be in place until the Cabinet announced a new land policy in February 1997. This meant that for a period of about twenty months, one arm of policy was operating to impose more losses on banks while another arm sought to transfer these (contingent) losses to the government's balance sheet. 
More to the point, it made little sense to rely on monetary policy to deliver growth if the main transmission mechanism of monetary policycredit transmission through the banking system-was inoperable, and likely to remain so for a number of years as the government gave the banks time to repair their balance sheet wounds slowly. This was a policy contradiction in terms. In effect, the implicit policy in Japan for a decade was to rely on a 'broken' banking system as the primary transmission channel (of monetary policy) for fixing itself. No wonder the economy floundered!

What could, and should, the government have done instead? In short, the government should have implemented a coordinated and strategic package of macro and micro policies, centring on three elements. At the macro level, the authorities should have announced that macro-level deflation would not be tolerated and implemented a sustained and coordinated fiscal and monetary expansion to be continued until the economy emerged from deflation. Bridging the macro and micro levels, the authorities should have fixed the banking system by injecting enough fiscal funds into the banking system to enable banks expeditiously to clear away bubble-era excess corporate debt and recapitalise themselves. Conceptually, this capital injection could be thought of as the government 'marking to market' its guarantee of deposits since by fully guaranteeing bank deposits the government became the contingent owner of any residual losses in the banking system associated with the balance sheet cleanup after bank equity was wiped out. At the micro level, the government should have pursued an aggressive program of deregulation and public sector reform (rather than a slow and piecemeal one) so to open up new consumption and investment opportunities and raise the potential growth rate.

The policy framework in existence in 2005 rested on the same principles and embodied the same flaws. Under the policy framework as re-defined by the Koizumi administration, the economy was envisaged as being in the final year of a 3-4 year 'intensive adjustment period'. The aim during this time was to 'complete the resolution of the non-performing loan problem' and establish the conditions for the economy to exit from deflation. The Bank of Japan was committed to maintaining its 
extraordinary quantitative easing regime until it was 'convinced' that the economy would not slip back into deflation (as measured by the core CPI). The government continued to fully guarantee large-lot demand deposits (some 31 per cent of total bank deposits) and, in effect (via the financial crisis response framework in the deposit insurance system) to fully guarantee all bank deposits. In short, the economy had not yet emerged from its post-bubble deflationary path and policy was still in post-bubble deflation-fighting, financial system-stabilising mode.

The authorities continued to use two central planks of policy-financial stabilisation policy centring on guarantees of bank deposits, and monetary policy - to 'play for time' and 'bank on growth'. The problem is that, as in the past, these policies were unlikely to deliver an end to deflation and a transition to sustainable growth. Japan is by no means out of the postbubble deflationary woods, notwithstanding the recent impressive-looking real growth rates (Table 1.3).

First, take bank guarantees. The government continued, in effect, to fully guarantee all bank deposits. Initially the blanket government guarantee on bank deposits was supposed to expire at the end of March 2001, after which time only small-lot deposits would be automatically guaranteed by the deposit insurance system (what the Japanese refer to as 'the pay-off system). However, the government extended the guarantee on large-lot time deposits to the end of March 2002, and the guarantee on large-lot demand deposits ('large-lot' being deposits above 10 million yen per depositor per bank) first to the end of March 2003 but then later to the end of March 2005. On paper, the government allowed the blanket guarantee on large-lot time deposits to expire at the end of March 2002. This change in formal guarantee status had the predictable effect: it triggered a huge shift in deposits from time deposits to demand deposits, since under quantitative easing (zero interest policy) these deposits were almost perfect substitutes, other than in their guarantee status, which clearly favoured demand deposits (Figure 1.8).

A key choreography of policy in Japan was that the remaining government guarantee on large-lot bank deposits would expire at the end of March 2005, ushering in the era of the 'full pay-off regime'. If only that were the case! This portrayal is, at best, wishful thinking, at worst 


\section{Table 1.3 Japan's banking system workout framework, 2004}

Deposit Insurance Corporation (DIC) and

Industrial Revitalisation Corporation (IRC)

loan guarantees (yen tr)

Depositor protection

NPL purchases by RCC

RCC losses/recapitalisation

Financial crisis response

'Old' bank recapitalisation

'New' bank recapitalisation (planned from FY04)

DIC investment in IRC

DIC sub-total

IRC funds

Total

Maximum
amount

Amount

used

Amount

available

$\begin{array}{rrr}19.00 & 5.01 & 13.99 \\ 14.00 & 4.56 & 9.44 \\ 6.00 & 0.81 & 5.19 \\ 17.00 & 1.96 & 15.04 \\ 1.00 & 0.01 & 0.99 \\ 2.00 & 0.00 & 2.00 \\ 0.15 & 0.15 & 0.00 \\ 59.15 & 12.49 & 46.66 \\ 10.00 & 0.51 & 9.49 \\ 69.15 & 13.00 & 56.15\end{array}$

Sources: Deposit Insurance Corporation of Japan; Industrial Revitalisation Corporation of Japan; Nikkei newspaper.

Figure 1.8 Shift in large-lot time deposits, triggered by removal of guarantee, 1995-2007 (per cent year-on-year)

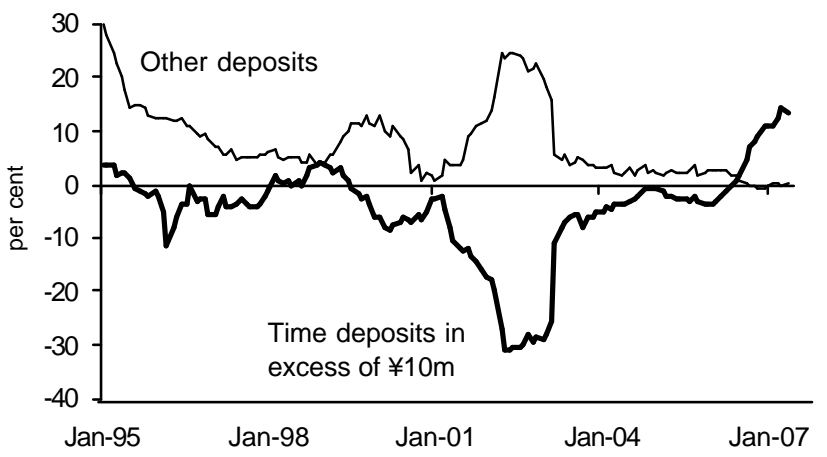

Source: Bank of Japan. 
disingenuous. True, under sunset legislation, the blanket guarantee on large-lot demand deposits expired at the end of March 2005, and the authorities did not extend this guarantee for a third time. This deadline coincided (purposely) with the target date for the completion of the government's 'financial revival program' (the so-called 'Takenaka plan') unveiled at the end of October 2002 (Japan, Financial Services Agency 2002).

However, there were two loopholes relating to this change in the status of the government guarantee of bank deposits. One is that, under legislation passed in December 2002, deposits earning a zero interest rate (so-called 'settlement deposits') continued to be fully guaranteed. There was no 'payoff for these deposits, which at the time represented about 21.1 per cent of large-lot demand deposits and 6.5 per cent of total deposits. This created a loophole in the removal of the government guarantee, as interest rates at the time were so close to zero that it hardly mattered ( 0.001 per cent): accepting a zero interest rate would mean giving up just 100 yen of interest income on a minimum-size large-lot deposit (10 million yen). This meant that, should there be lingering concerns about the strength of bank balance sheets or should such concerns re-surface, there could well have been a shift from non-zero large-lot demand deposits to zero demand deposits, analogous to (although likely not on the same scale as) the shift from time to demand deposits triggered by the removal of the automatic guarantee on the former (Figure 1.8).

A second loophole was more systemic: even when the blanket guarantee expired, a state of affairs that was tantamount to a full government guarantee on bank deposits continued to exist. The 'financial crisis response' framework, which came into existence in April 2001, can be used whenever 'it is feared that, should measures not be implemented, very severe obstacles would arise in the maintenance of orderly credit [conditions] in the country or in the region where the financial institution in question operates' (Deposit Insurance Law, Article 102). This framework has been invoked on two occasions, to provide a capital injection to Resona Bank and to nationalise Ashikaga Bank. It is designed in such a way that, whenever it is invoked, the deposits of the financial institution concerned are fully guaranteed. ${ }^{1}$ The blanket guarantee was introduced in 1995 in order to head off a 
financial crisis; the thrust of the framework that replaces it is that deposits will continue to be fully guaranteed after the event if that is necessary in order to maintain financial stability. Put another way, the blanket guarantee is to be removed, but only in those cases in which is not needed.

\section{A policy critique of forbearance}

Japanese policymakers appear to take it as self-evident that it is sound policy for the government to fully guarantee bank deposits. After all, as long as the market retains confidence in the sovereign credit, it is a surefire way to prevent a run on bank deposits and to maintain financial stability. And it is cheap-as long as the guarantees are not called in, there is no overt fiscal cost.

However, as a policy tool, government guarantees of bank deposits have a serious drawback: they serve to slow down the whole bank resolution process and impose a high cost on the economy in terms of lost growth and the ultimate fiscal costs incurred. In fact, the very thing that makes government bank deposit guarantees so potent in putting out financial system fires - the removal of the balance sheet pressure on banks and of the need for depositors to worry about the safety of the principal they have invested in the banking system-creates a bias in this direction. This can be counter-productive in the long run, however, as by virtue of the success of the deposit guarantees, the underlying problems are prevented from surfacing, and hence are slow to be addressed.

Disclosure, and credibility of the regulatory framework, also suffer under a policy of forbearance, the more so the bigger the scale of the underlying problem. The decision to take what on any official reckoning would be almost ten years from the official recognition of the problem (which I date to June 1995) to its aimed-for resolution (March 2005) to restore balance sheets to sufficient health for banks to operate without being propped up by the government implies that full information about the 'true' (such as that can be ascertained at all) underlying state of bank balance sheets can only be revealed gradually over time. This is because, had the 'true' state of bank balance sheets been revealed at the start of the process, the market, political, regulatory, and popular pressures for dealing more quickly with the problems would have forced immediate policy action, contradicting 
the underlying assumption of forbearance. Incremental and minimalist action goes hand-in-hand with incremental disclosure. However, enormous damage is inflicted on the credibility of the regulatory framework, as each incremental bank failure puts the spotlight on how much has been covered up in the past and for how long.

More generally, the use of extraordinary deposit guarantees, after the event, to deal with a banking crisis involves a trade-off. By converting increasingly risky claims on bank assets into safe claims on the government, such guarantees prevent a damaging financial crisis from erupting, but at the same time they serve to impede the recognition of losses and the necessary balance sheet adjustment process. This suggests that ex post guarantees and forbearance work best when the damage to bank assets is small and/or temporary. The extraordinary guarantee then serves to bridge the inherent asset/liability mismatch in a banking system's balance sheet. But if the assets have permanently disappeared, as in Japan's case (see Figure 1.1), there is little to be gained in 'playing for time' in the hope that asset values will be restored, whereas the long-term costs of not recognising and reacting to such a fundamental change in balance sheet circumstances are high. Given Japan's situation, where the banking problem clearly involved a one-off monumental loss of asset value rather than a temporary one which could be expected to reverse itself with time, forbearance has offered a particularly poor benefit-cost trade-off.

The second plank of policy, complementing the use of government bank deposits guarantees, was the easing of monetary policy. Three years after the Bank of Japan cut official interest rates to 50 basis points in September 1995, the Bank had to start to cut rates even further, culminating in an unprecedented policy of zero interest rates in February 1999. Following an abortive and controversial attempt to raise rates in August 2000, the Bank of Japan abandoned interest rate targeting in March 2001 and moved to 'quantitative targeting' (or 'quantitative easing'), implying zero overnight interest rates but going well beyond that in terms of the provision of reserves to the banking system (Figure 1.9). According to the Bank of Japan, it 'decided to implement these policy measures with firm determination with a view to preventing prices from declining continuously as well as preparing a basis for sustainable economic growth' ${ }^{2}$ 
Figure 1.9 Bank of Japan quantitative easing: current account balances targets, 2001-2006 (yen trillion)

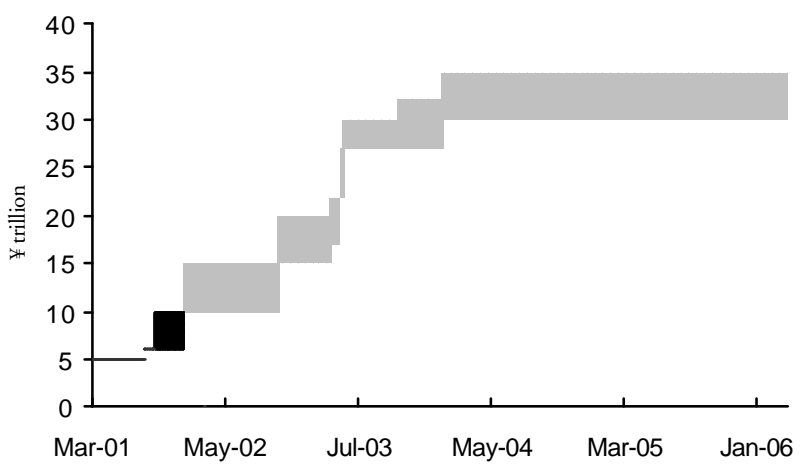

Source: Bank of Japan.

According to economic theory, easing monetary policy when the economy is on the verge of, or actually in, deflation is definitely the right policy. However, there has to be a transmission mechanism. The credit transmission mechanism, through the banking system, is the natural candidate, particularly in an economy such as Japan's with its dominant banking system. However, if the corporate sector has a huge overhang of excess debt on its balance sheets due to the bursting of a massive realestate price bubble, and if the banking system does not have the capital to take quick action to clean up both its and the corporate sector's balance sheets, then monetary policy may not be effective in getting the economy out of deflation and onto a sustainable growth path. This has been the case in Japan.

As Figure 1.10 shows, bank lending had been falling since about 1996, and particularly sharply since 1998. In terms of stimulating the economy, banking system policy had been working at cross-purposes to monetary policy. Monetary policy had been relied upon, rather than a more sensible coordinated fiscal-monetary policy, as the principal anti-deflation tool in the forbearance policy framework. Yet there has been a glaring contradiction in the policy approach: monetary policy has been expected to work through 
Figure 1.10 Bank lending growth: headline, adjusted for special factors, 1995-2007 (per cent year-on-year change)

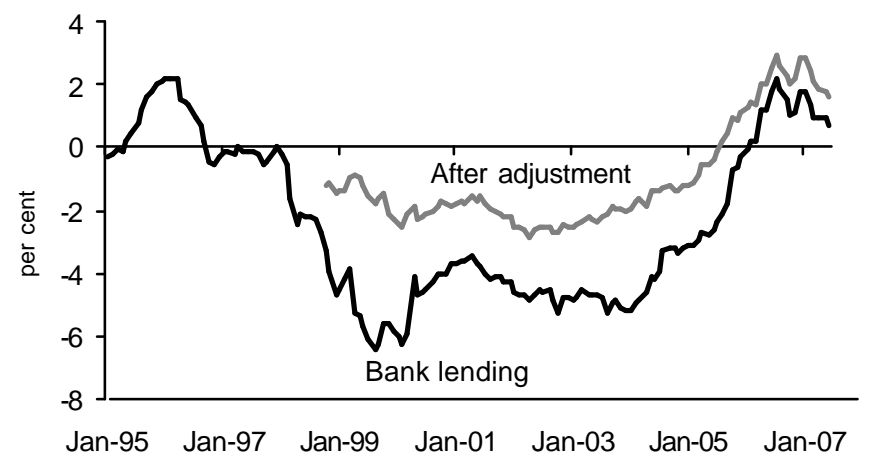

Note: 'Special factors' include NPLs and so on.

Source: Bank of Japan.

the credit transmission process of a banking system to help rescue a banking system that had been deflating. A damaging policy circularity is thus created: the banking system is given time to help it 'grow out of its problem, but without a sound banking system, strong and sustained growth is difficult.

Figure 1.11 shows the conundrum at work. After quantitative easing began, base money increased by a cumulative 64 per cent, driven by the policy-induced increase in current account balances (mainly bank reserves), but bank lending fell by a cumulative 16 per cent during this period (March 2000-March 2004). Monetary policy was unable to gain traction through the banking system, and nominal GDP fell by 2 per cent over the period before finally rising after March 2006.

There are other transmission channels. Monetary economists focus particularly on the expectations channel. ${ }^{3}$ By communicating a strong message that deflation will not be tolerated and by taking aggressive monetary policy action aimed at achieving that goal, a central bank may be able to change private sector expectations, and hence consumption and investment behaviour, in a way that makes an exit from deflation a self- 
Figure 1.11 Monetary aggregates and nominal GDP, 2000-2007 (index, March 2001=100)

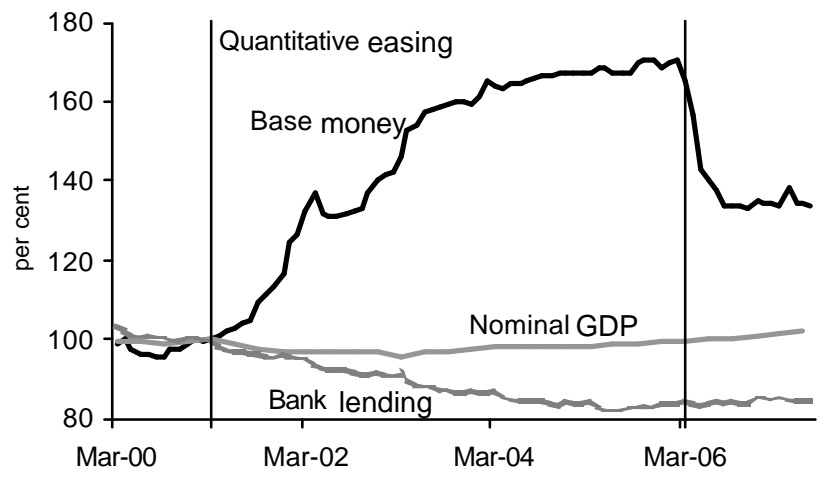

Sources: Bank of Japan; Cabinet Office.

fulfilling prophesy. ${ }^{4}$ However, the Bank of Japan consistently eschewed reliance on, or belief in the potential efficacy of, the expectations channel, on the grounds that the transmission mechanism of monetary policy was impaired and therefore the means by which monetary policy could operate upon expectations was lacking.

There are two responses to this kind of claim. One is that it is wrong, accepting that 'one can argue that monetary policy works mostly (entirely?) through its effects on expectations' (Blanchard 2000:191). In that case, however, the damage is done because the denial by the Bank of Japan that it could influence expectations is tantamount to a declaration not to rely on this channel. Ironically, such beliefs by a central bank will be selfreinforcing. Another is to accept the logic, but to argue the obvious point that, if the transmission mechanism of monetary policy is 'broken', then it should be 'fixed' as a matter of the highest policy priority. Policymakers, time and time again in Japan, have appeared to accept this logic, and have appeared to be in the process of developing plans to fix the banking system, only to disappoint by failing to execute policy.

One could point in particular to: the 1996 'financial stabilisation fiveyear plan', which purported to have the aim of 'bringing the non- 
performing loan problem under control by the end of FY00'; the 1998 'finance Diet' which produced the 60 trillion yen bank work-out plan (whose successor is outlined in Table 1.4) (Financial System Council 1995); the April 2001 'emergency economic package' that pointed to 'the existence of excessive corporate debt', the 'delay in balance sheet adjustments [imposing] a heavy burden on economic growth', and the fact that 'without a quick resolution of this issue, [firm] progress towards economic recovery cannot be expected', thus (to paraphrase) 'the critical importance of solving such structural issues still present in the asset markets for the Japanese economy to achieve dynamic growth' (Ministerial conference 2001); the June 2001 blueprint document laying out the Koizumi structural reform agenda, whose starting point aim was to 'resolve the non-performing loans problem within two or three years' (Council on Economic Fiscal Policy 2001); and the October 2002 'financial revival program' (the so-called 'Takenaka plan'), which took as its starting point the 'need to solve the non-performing loan problems of the major banks' by focusing on 'making asset evaluations stricter, bolstering capital levels, and strengthening governance'. Notwithstanding the no doubt well-intentioned policy rhetoric and the numerous associated schemes introduced, official nonperforming loan levels, fell from March 2002 peak levels, but remained almost as high as they were at the start of the official work-out in 1996 (Figure 1.4), and there were no signs of the banking system becoming an effective transmitter of monetary policy (Figures 1.10 and 1.11).

Table $1.4 \quad$ Foreign exchange intervention, 1999-2003 (yen trillion)

\begin{tabular}{lccccc}
\hline & FY99 & FY00 & FY01 & FY02 & FY03 \\
$1 \mathrm{Q}$ & 3.039 & 1.385 & 0.000 & 4.016 & 4.612 \\
$2 \mathrm{Q}$ & 2.388 & 0.000 & 0.000 & 0.000 & 5.876 \\
$3 \mathrm{Q}$ & 1.634 & 0.000 & 0.000 & 2.387 & 7.551 \\
$4 \mathrm{Q}$ & 1.558 & 0.144 & 3.211 & 0.000 & 14.832 \\
Total & 8.628 & 1.529 & 3.211 & 6.403 & 32.870 \\
Per cent yen/ & 12.4 & -12.4 & -7.4 & 10.5 & 9.3 \\
\multicolumn{2}{l}{ dollar appreciation* } & & & & \\
\hline
\end{tabular}

* using March averages

Source: Ministry of Finance. 
It is a similar story with the Bank of Japan, when it comes to fixing the banks. When the Bank of Japan implemented 'zero interest rate policy' in February 1999 it stated that: 'In order to bring [the] Japanese economy back to a solid recovery path, it is important not only to provide support from monetary and fiscal sides but also to steadily promote financial system revitalisation and structural reforms. The Bank of Japan strongly hopes that the decision to make money market operations more accommodative will, combined with various efforts made by the parties concerned, contribute to surmounting the economic difficulties we face' (Bank of Japan 1999). When the Bank introduced quantitative targeting in March 2001, it similarly stated

In order to make this monetary easing fully effective in restoring Japan's economy on a sustainable growth path, progress in structural reforms with respect to the financial system, for example, resolution of the nonperforming asset problem, as well as in the area of economy and industry is essential. Structural reform may be accompanied by painful adjustments. Without such adjustments, however, neither improvement in productivity nor sustainable economic growth can be obtained. The Bank of Japan strongly hopes that decisive actions be taken to address fundamental problems both with a clear support of the nation for structural reform and under a strong leadership of the government of Japan (Bank of Japan 2001, point 5).

In September 2002, the Bank of Japan announced a 'new initiative towards financial system stability', unveiling a 'course of action to facilitate resolution of the non-performing loan problem and to secure financial system stability'. The Bank argued that 'in order to resolve the overall problem, a comprehensive and is needed, centring on a more appropriate evaluation of non-performing loans, the promotion of their early disposal, and efforts toward higher profitability on the part of both firms and financial institutions'. The Bank pledged to 'conduct a comprehensive review of the non-performing loan problem and publish the result' (Bank of Japan 2002) and the next month announced that it would take the extraordinary step of buying up to 2 trillion yen of equities held by banks (increased to 3 trillion yen in March 2003) (Bank of Japan 2002). At the time, this was widely regarded as a case of the Bank of Japan having thrown the central 
bank equivalent of a hand grenade at the banking authorities. However, judged by ultimate results, which is what counts, the results were disappointing.

Things appeared to have taken a serious turn for the good in March 2003, when, virtually immediately upon assuming office, the new governor of the Bank of Japan, Toshihiko Fukui, called an extraordinary monetary policy meeting, at which he instructed Bank staff to examine a wide range of issues related to the enhancement of monetary policy transparency and the strengthening of the monetary policy transmission mechanism based on the experience of quantitative easing so far' and 'with respect to specific measures, ... particularly instructed Bank staff to explore possible measures to strengthen the transmission mechanism of monetary easing in the areas of corporate finance and money market operations' (Bank of Japan 2003). However, what came out of this initiative in terms of measures aimed at strengthening the transmission mechanism was an anticlimax: a scheme to purchase by March 2006 up to 1 trillion yen of asset-backed securities (mainly) of small and medium-sized enterprises. But 1 trillion yen is equivalent to only 0.2 per cent of Japan's GDP or 1 per cent of monetary base, and is only a drop in the macro bucket when it comes to getting the credit transmission mechanism working in Japan. Actual implementation of the scheme has been even more modest, with the Bank currently holding only 192 billion yen of asset-backed securities under this scheme an amount equivalent to less than 0.2 per cent of monetary base (Figure 1.12).

The government had a well-articulated (albeit flawed) framework for carrying out a banking system work-out (Table 1.3). Aggressive use of this framework, to give the banks directly or indirectly enough capital to remove the corporate debt overhang, would have helped to establish the pre-conditions for the credit contraction process to be brought to an early end, and for monetary policy to start to gain traction through the banking system. It still could have. However, notwithstanding the recapitalisation of the fifth largest banking group and the nationalisation of the tenth largest regional bank in 2003, the Bank of Japan persisted with its deepseated reluctance to use the framework to expedite a work-out rather than as a tool of forbearance. 
Figure 1.12 Purchases of asset-backed securities by the Bank of Japan, 2003-2006

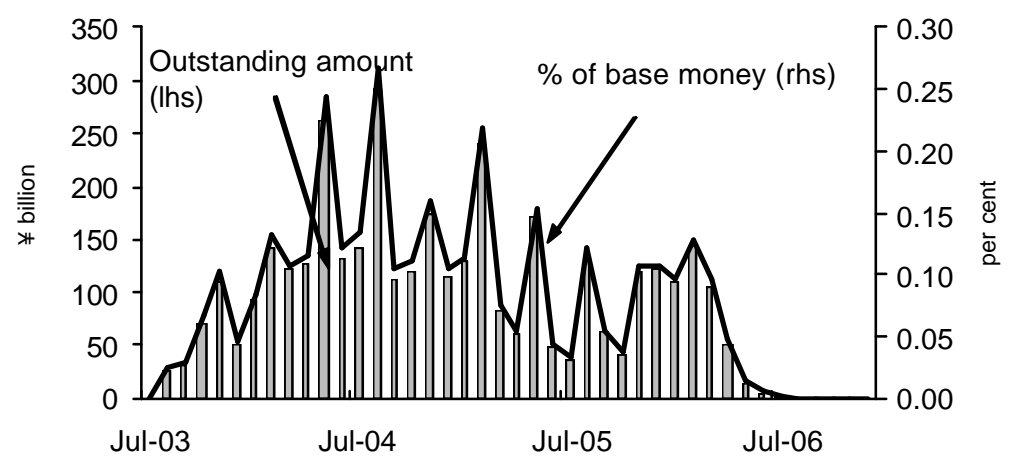

Source: Bank of Japan.

If actions speak louder than words, the transmission channel that the authorities are really prepared to use is the exchange rate. Japan conducted unprecedented foreign exchange intervention in the FY 2003, selling 32.87 trillion yen of domestic currency to buy (overwhelmingly in US dollars) an amount equivalent to about twice Japan's annual current account surplus (Table 1.4). As a result, Japan's foreign exchange reserves increased to US\$806 billion at the end of March, an increase of 69 per cent year-onyear (Figure 1.13). In the course of accumulating so many foreign reserves, the Ministry of Finance literally ran out of money, running up against its Diet-authorised borrowing limit by the end of 2003. Not to be deterred, the Ministry of Finance temporarily 'borrowed' the central bank's balance sheet, by entering an agreement with the Bank of Japan on 26 December to purchase up to 10 trillion yen of the Ministry's foreign exchange reserves (which it did in the first two months of 2004). Moreover, the authorities signaled to the market that they would be prepared to continue with this policy on even a larger scale if necessary. The Ministry increased the total budget available to raise intervention funds from 79 trillion yen in FY2003 to 140 trillion yen in FY2004 (in two stages, 21 trillion yen in the FY2003 supplementary budget and 40 trillion yen in the FY2004 Budget). 
Figure 1.13 Foreign exchange intervention and official reserves, 1994-2004

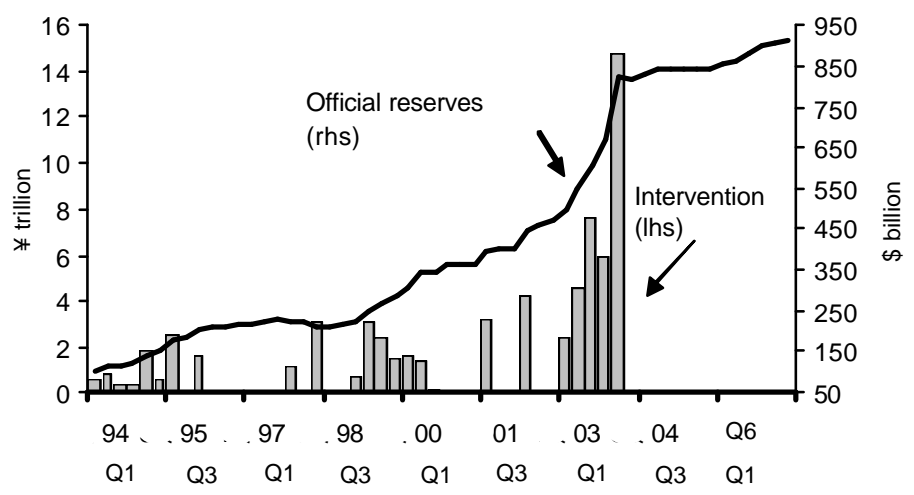

Source: Ministry of Finance.

While massive foreign exchange intervention backed up by monetary easing has its merits as a policy to overcome deflation, there are a number of problems. One, the idea seems to be at odds with policymakers' own diagnosis and prescription for countering deflation, as laid out in numerous policy documents. Two, and related, the policy stimulus would appear to be poorly directed, because the export sector arguably is already strong and the transmission mechanism from an export-led recovery to domestic demand appears to be weak. Three, policy implementation has been poor, in that the authorities have not communicated a strong and coordinated anti-deflation message between the Ministry of Finance and the Bank of Japan, such as could have had a significant impact on expectations.

\section{Conclusion: what may lie ahead}

Despite the recently improved sentiment towards Japan, surveying the economic landscape in 2005 it appeared that neither the government nor the market was expecting the economy to resume robust growth any time soon. One of the casualties of the post-bubble period has been bullish growth expectations about the future. According to the government's own 
medium-term fiscal and economic plan, under the scenario in which the government successfully discharges its reform plans during the 'intensive adjustment phase' after which the economy achieves sustainable growth, real growth would average 2 per cent over the next five years (and only 2.1 per cent in FY2008) and nominal GDP growth 1.9 per cent. According to the Consensus Economics numbers of major market forecasters at the time, the market consensus was that growth would be 4.2 per cent in 2004 , but would decelerate to 1.8 per cent in 2005. Thus the consensus appeared to be forecasting that this third post-bubble recovery would stay within the post-bubble trend of low-growth, deflationary cyclical ups-and-downs.

While Japanese policymakers talked about the need to put an end to deflation and get the economy on a sustainable (domestic demand-led) growth path again, they did not appear to have a credible policy framework in place to bring that about, and it was unlikely to happen autonomously. The most likely scenario was that policy 'muddling-through' would continue, based on defensive and open-ended deflation-fighting policies, with intermittent periods of more aggressive policy responses triggered by market (crisis) events, and this is what occurred.

As of mid 2007, Japan is on the road to becoming a 'normal', albeit lower growth, economy again. The listed banking sector, adequately capitalised by a more than trebling of its market capitalisation since its April 2003 trough, is largely able to stand on its own feet again, and the Bank of Japan has started to move policy rates into positive territory for the first time in seven years. However, deflation is not fully vanquished in Japan, as evidenced by both the GDP deflator and the core CPI being in slight negative territory in year-on-year rate of change terms $(-0.3$ per cent and -0.1 per cent respectively).

As long as Japan remains trapped in a quasi-deflationary twilight zone, and assuming that China can keep on its current high-growth coursereminiscent in many ways of Japan's own high-growth period-the relentless slide in Japan's relative standing as an economic powerhouse in Asia looks set to continue. This prospect does not augur well for Japan to exercise an economic leadership role in Asia commensurate with its economic responsibilities and potential. 


\section{Notes}

1 Even if a bank is nationalised, and even when there is no ex ante guarantee on large-lot deposits (that is, the 'pay-off is in effect), there is no way within the framework to impose a 'haircut' on depositors. Thus, when Ashikaga Bank was nationalised, it was immediately announced that all depositors would be guaranteed. Few observers seemed to comment on the apparent inconsistency of this automatic ex post guarantee with the 'partial pay-off, in effect from 1 April 2002.

2 Bank of Japan, 'New Procedures for Money Market Operations and Monetary Easing', 19 March 2001.

3 To quote Michael Woodford on the general topic: 'Not only do expectations about policy matter, but, at least under current conditions, very little else matters' (Interest and Prices: Foundations of a Theory of Monetary Policy, Princeton University Press, Princeton, 2003:15).

4 This was clearly the strategy employed by the Federal Reserve in 2003 when Chairman Alan Greenspan and Governor Ben Bernanke, particularly the latter, pointed in public speeches or comments to the implausibility of a central bank with a fiat currency and a 'printing press' not being able to counter deflation.

5 See Olivier Blanchard, 2000: 'Bubbles, liquidity traps, and monetary policy', in Ryoichi Mikitani and Adam S. Posen (eds), Japan's Financial Crisis and its Parallels to US Experience, Washington, DC:185-93.

\section{References}

Bank of Japan, 1999. Change of the Guideline for Money Market Operations.

—_, 2001. "New Procedures for Money Market Operations and Monetary Easing' point 5, 19 March.

_ 2002. 'New Initiative toward Financial System Stability' [English statement on Bank of Japan website], 18 September.

__, 2002. 'The Outline of the Stock Purchasing Plan', (English statement on Bank of Japan website), 11 October.

_ 2003. Bank of Japan Monetary Policy Meeting, (taken from English statement on Bank of Japan website), March.

Council on Economic Fiscal Policy, 2001. Council on Economic Fiscal Policy (Basic principles for structural reform of economic and fiscal management and structural reform of economic society), 26 June 33:1. Financial System Council, 1995. Financial System Council ['Kin'yu shisutemu anteika no tame no shisaku'], (various measures for the stabilisation of the financial system), 22 December.

Japan, Deposit Insurance Law 2001. Deposit Insurance Corporation of Japan, website www.dic.go.jp. 
Japan, Ministry of Finance, 1995. 'Kinyu shisutemu no kino kaifuku ni tsuite (On restoring the functioning of the financial system)' (mimeo document).

Japan, Financial Services Agency, 2002. Kin’yu saisei puroguramu (Financial revival program), 30 October: 1.

Ministerial statement at ministerial conference for economic measures, 2001. (B11pp (quotes are from p.1, 6 April). 